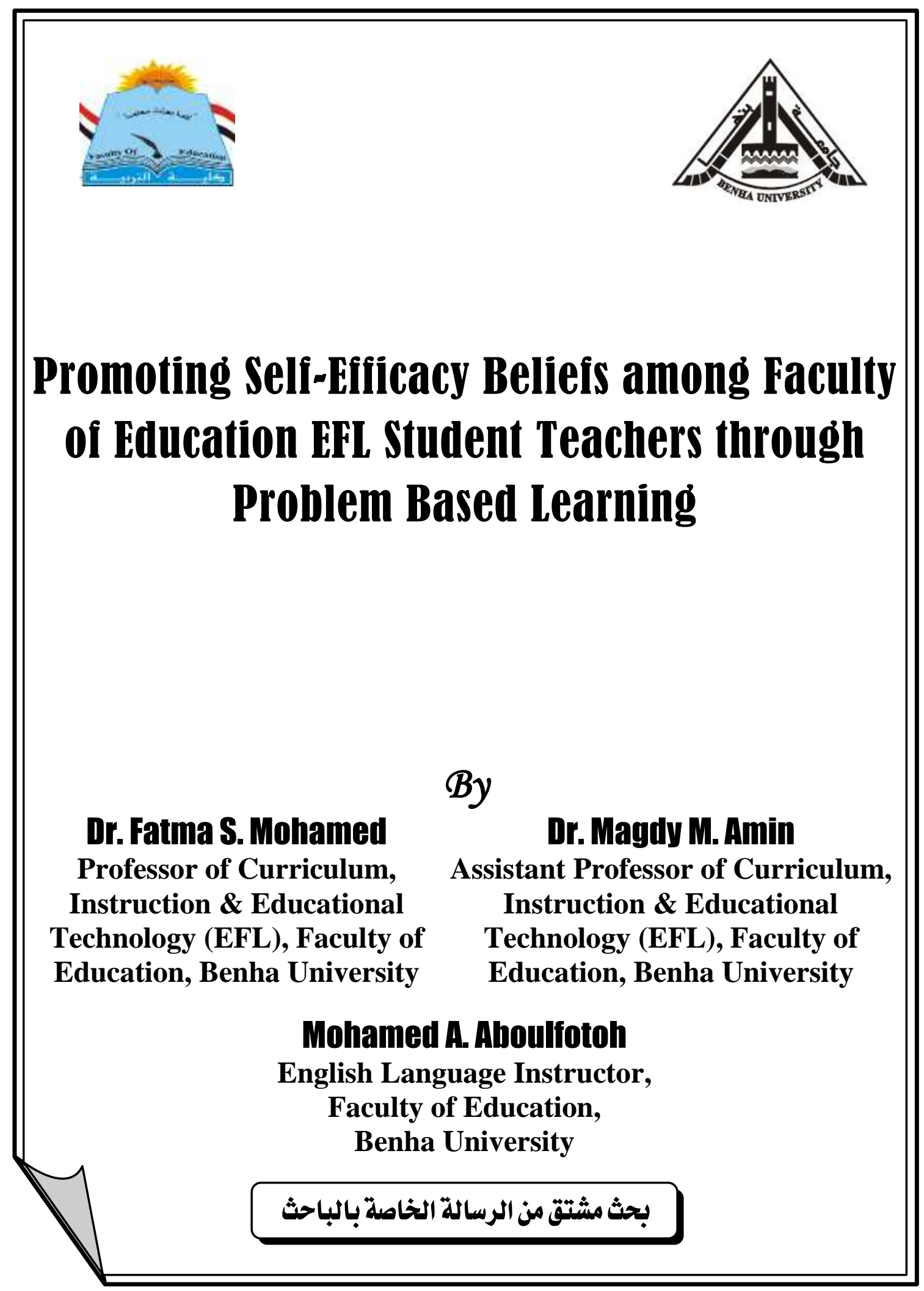




\section{Promoting Self-Efficacy Beliefs among Faculty of Education EFL Student Teachers through Problem Based Learning}

Dr. Fatma S. Mohamed

Professor of Curriculum, Instruction \& Educational Technology (EFL), Faculty of Education, Benha University
By

\section{Mohamed A. Aboulfotoh}

English Language Instructor,

Faculty of Education, Benha University

\section{Dr. Magdy M.Amin}

Assistant Professor of Curriculum, Instruction \& Educational Technology (EFL), Faculty of Education, Benha University

\section{Abstract}

The present research aimed at improving EFL fourth year student teachers' teaching self-efficacy through Problem Based Learning (PBL). Participants of the research were selected from the fourth year student teachers at Faculty of Education, Benha University, in the academic year 2018/2019. They were randomly assigned into two groups: experimental $(n=30)$ and control $(n=30)$. The instruments of the research were a prepost scale of teaching self-efficacy (adopted from Hammam's final version, 2016) and a reflection form (prepared by the researcher). The research adopted the pre-post experimental/control group design. Results of the research revealed that the experimental group teaching selfefficacy was significantly higher than the control group. Thus, it is recommended to use PBL in improving teaching self-efficacy at the Faculties of Education in Egypt.

Keywords: Problem Based Learning, teaching self-efficacy, student teachers. 


\section{Research Problem and its Context}

\section{Background of the Problem}

Teaching English takes place in a world of rapid developments that require a response to the real world. Teaching as a process includes the teacher, student, method and content. Of all of them, the teacher is the effective anchor to be developed professionally to meet the high standards of teaching and raise the levels of achievement in schools. Developing EFL teachers' performance requires not only to acquire teaching knowledge and skills but also "Teaching Self-Efficacy".

The concept of self-efficacy was originally developed by Bandura (1997) as a part of his social-cognitive theory. Bandura defined selfefficacy as 'teachers' beliefs about their capabilities to produce designated levels of performance (p.71)". Teachers' efficacy has two dimensions: general and personal teaching efficacy. The former refers to the extent to which they believe that their efficacy in teaching is limited by factors outside their control or control of the school (e.g. family background, social class and intelligence) whereas the latter refers to the conviction in their ability to control students; motivation and achievement.

According to the Faculties of Education Enhancement Project (FOEP) in Egypt $(2005,1: 2)$, the goals of developing Teacher Education Programs(TEPs) at the Faculties of Education are updating their views and conceptions with reference to the international innovations, and emphasizing the teaching self-efficacy that directs student teachers' performance. On the other hand, Toba $(2006,2: 4)$ found that most of student teachers are shocked by the real teaching context. Preparation performance standards discovered big gaps in current TEPs. Miller (2008) examined learning contexts that can encourage them to approach, reframe, and make sense of these gaps or problems. He asked "What happens to pre-service teachers' conceptions of teaching practice and student learning if their problems are used as a mechanism for their professional development (p.78)?" 
Self-efficacy beliefs are initially informed by teachers' schooling and L2 learning experience. Input from TEP and reflection on classroom experience is filtered by the beliefs before it becomes "intake," which in turn is filtered before teachers incorporate it into their daily teaching to become "uptake" (Phipps, 2010: 21). Teacher self-efficacy is the belief that teachers have in their own abilities and skills as educators. These beliefs influence thought patterns and emotions, which, in turn, enable or inhibit actions. It has been proven that teachers' belief in their own abilities positively affects the actions of teachers as well as styles of teaching, classroom management, and other teacher characteristics (Gavora,2011, 80: 81).

Borg (2011:3) indicated that what teachers think, know and believe have an influence on what they do in the class. Teachers' beliefs are shaped by thier prior learning and teaching experiences, and what they do is influenced by the interaction between their beliefs and contexts. El-sweedy (2012:46) viewed teaching self-efficacy from two perspectives. First, it's their individual beliefs in their capabilities to design and perform effective teaching tasks at a specified level of quality in specified class situations. Second, it's teachers' belief in their ability to affect students' performance and the degree to which outcomes are affected by teachers. Importantly, Ahmad (2014:4) pointed to the positive effect of self-efficacy on teachers' teaching skills. It helped them maintain discipline and manage class, use innovative teaching strategies, and use technology in the class.

Al-Shukri (2016) examined EFL teachers' self-efficacy beliefs, its sources and factors, and the relationship between EFL self-efficacy beliefs and teachers' practices. Results of the study revealed that teacher selfefficacy has positive impacts on different aspects of teaching and learning.

There is a relationship between PBL and teaching self-efficacy, PBL exposes student teachers to the complex situations which they will encounter and captures the essence of constructivist and social constructivist learning theories (Peters, 2006: 27). In PBL, teachers acquire knowledge through engaging in authentic problems and operate in small groups to solve those using resources available to them (HmeloSilver and Barrows, 2008, 48:94). PBL is an active learning strategy as 
student teachers are engaged in designing problems. Each problem cycle concludes with a reflection phase (Walker \& Leary, 2009: 43). PBL is designed to foster the intentional professional development of the student teachers (Brears, MacIntyre \& O'Sullivan, 2011:2).

It is clear that PBL fosters the four sources of self-efficacy described by Bandura: prior accomplishments, vicarious experiences, verbal persuasion, and lowered apprehension and stress about upcoming tasks. However, it has also been pointed out that the cooperative and collaborative group setting of PBL exerts influences on group members that mediate efficacy-enhancing.

\section{Context of the Problem}

In spite of the importance of teaching self-efficacy beliefs and the reciprocal relationship with EFL teaching skills, there is a low level among the fourth year student teachers enrolled in the English section, Faculty of Education, Benha University. The problem was indicated by the results of some studies: Gavora (2011); Abd El-Gawaad (2016); Ali (2016); Al-Shukri (2016); Hammam (2016) and Ra'afat (2016). Surveying these studies, it was concluded that student teachers' level is low in their teaching self-efficacy and teaching self-efficacy is needed to be highly developed in TEPs.

The researcher conducted unstructured interviews in the first term of the academic year 2015/2016 with EFL supervisors at practical education $(n=50)$ at Benha and Kfr Shoker Educational Administrations. The aim of the interviews was to get their observations concerning the fourth year student teachers' teaching self-efficacy. The interview comprised two questions:

- In your opinion, how does student teachers' confidence look like before, during and after the teaching situation?

- How can EFL student teachers respond to complex situations during teaching?

EFL supervisors' remarks were that most student teachers felt unrelaxed, had much fear during their teaching and lack self-confidence. 


\section{Statement of the Problem}

The problem of this research was "the low level of teaching selfefficacy among the fourth year student teachers, English section at Faculty of Education, Benha University". Thus, PBL is presented to face the problem.

\section{Questions of the Research}

To tackle the problem, this research attempted to answer the following questions:

- What are the perceived levels of teaching self-efficacy beliefs for:

a) engaging students, b) classroom management, and c) instructional strategies among fourth year student teachers, English section at Faculty of Education, Benha University?

- What is the effectiveness of Problem-Based Learning in improving teaching self-efficacy among the fourth year student teachers, English section at Faculty of Education, Benha University?

\section{Hypothesis of the Research}

The hypothesis stated that "there is a statistically significant difference between the mean scores of the experimental group and the control one of EFL teaching self-efficacy beliefs in the post-assessment at the level of $\alpha 0.05$, in favor of the experimental group".

\section{Delimitat1ions of the Research}

The study was limited to the following:

- A group of fourth year student teachers, English section at Faculty of Education, Benha University

- Some levels of teaching self-efficacy beliefs: a) engaging students, b) classroom management, and c) instructional strategies 


\section{Instruments of the Research}

To achieve the aims of the research, the following instruments were used:

- A Pre-post scale of Teaching Self-Efficacy to evaluate the level of teaching self- efficacy beliefs among student teachers. The scale was adapted from Hammam's final version $(2016,134: 136)$

- A Reflection Form to evaluate the level of student teachers' teaching self-efficacy beliefs before and after the PBL (prepared by the researcher)

\section{Participants of the Research}

The participants consisted of a control group $(n=30)$ and an experimental one $(n=30)$ of fourth year student teachers, English section at Faculty of Education, Benha University. The fourth year student teachers had been selected as they complete a certain instructional program that qualifies them to teach with confidence.

\section{Significance of the Research}

It was hoped that this research would be useful for:

- Student teachers as it will help develop their teaching selfefficacy.

- Curricula and training programs designers as it will provide them with the PBL to be taken into account when developing and designing EFL training courses.

\section{Terminology}

\section{Problem-Based Learning (PBL)}

Tan (2009: 206) defined PBL as a learner-centered strategy where unstructured (real-world) problems are used as the starting point for the learning process.

Savin-Baden (2014: 210) defined PBL as a "liquid learning" -in the sense that learning and knowledge are always on the move ... within and beyond disciplinary areas (p.210)". 
The operational definition of PBL is "an experiential learning in which student teachers solve real teaching problematic situations through collaborative inquiry, reflection, self-directed, and self-regulated learning".

\section{Teaching Self-Efficacy:}

Hammam (2016) described teaching self-efficacy as "student teachers' beliefs in their ability to use teaching skills to achieve desired outcomes and students' learning in EFL (p.11). The researcher adopted Hammam's definition as it is related to the purpose and participants of the research.

\section{Review of Literature and Related Studies}

\section{The Dependent Variable: Teaching Self-Efficacy}

\section{Categories of Teachers' Self-Efficacy}

Zheng (2015, 20:22) categorized teachers' beliefs of foreign language teaching into three areas: beliefs about EFL, EFL teaching and EFL teachers, and EFL learning and EFL learners. They are outlined in the figure below.

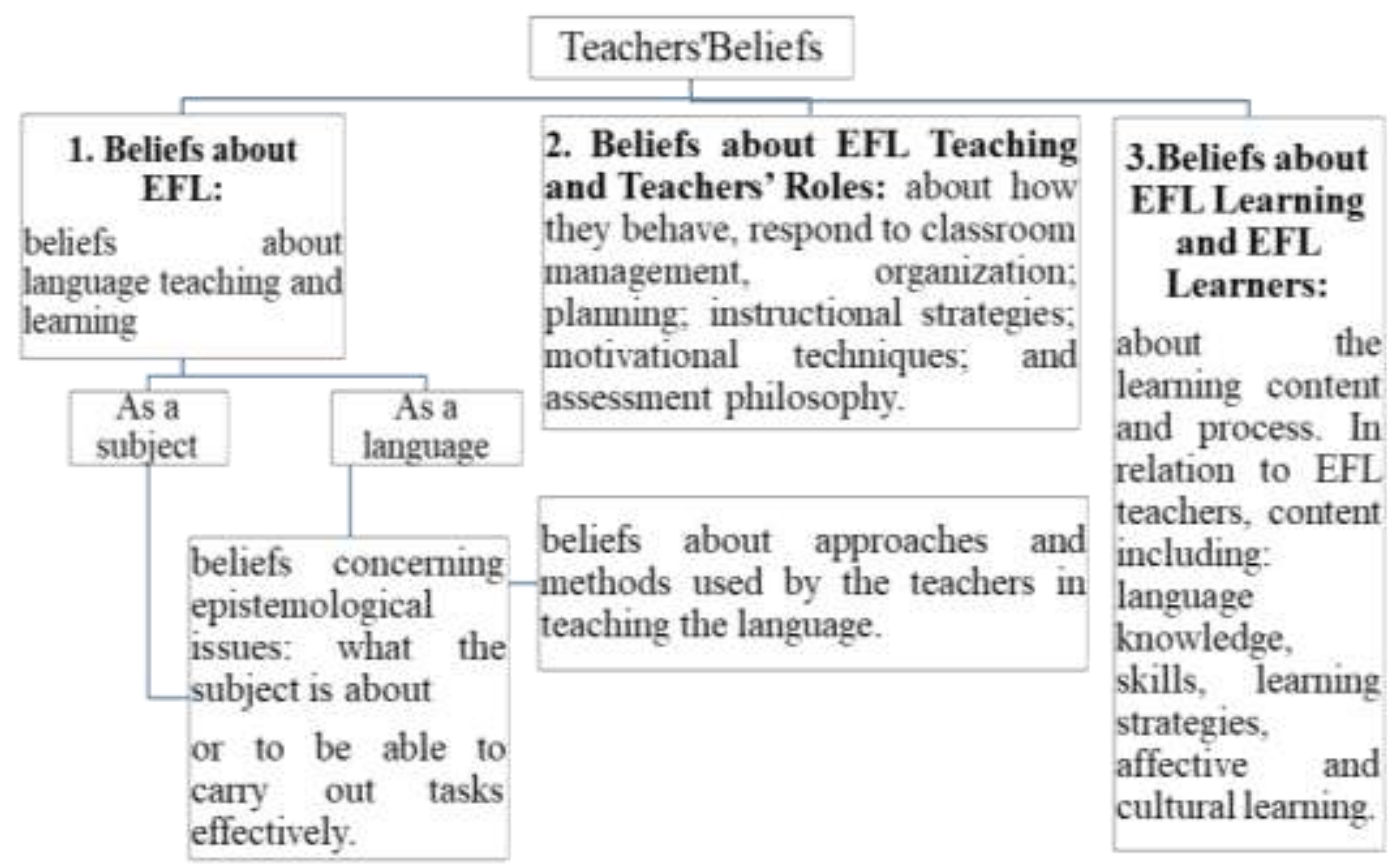

Figure (1): Categories of Teachers' Beliefs (Original Source) 
It's recommended that beliefs about EFL, EFL teaching and EFL teachers, and EFL learning and EFL learners should be considered in TEPs. TEPs should consider the relationship between teaching beliefs, practice and contexts.

\section{The Relationship Between Teaching Beliefs, Practice and Contexts}

Teachers' preparation is influenced by their self-efficacy, embedded in an integrated system that includes prior experiences; previous successes and failures, and feedback from others. Self-efficacy shapes how a teacher implement curriculum, predicts the success or failure of a textbook, or frame a teacher's response to a student's question (Blonder, Benny \& Jones, 2014: 3). The relationship can be outlined in the figure below:

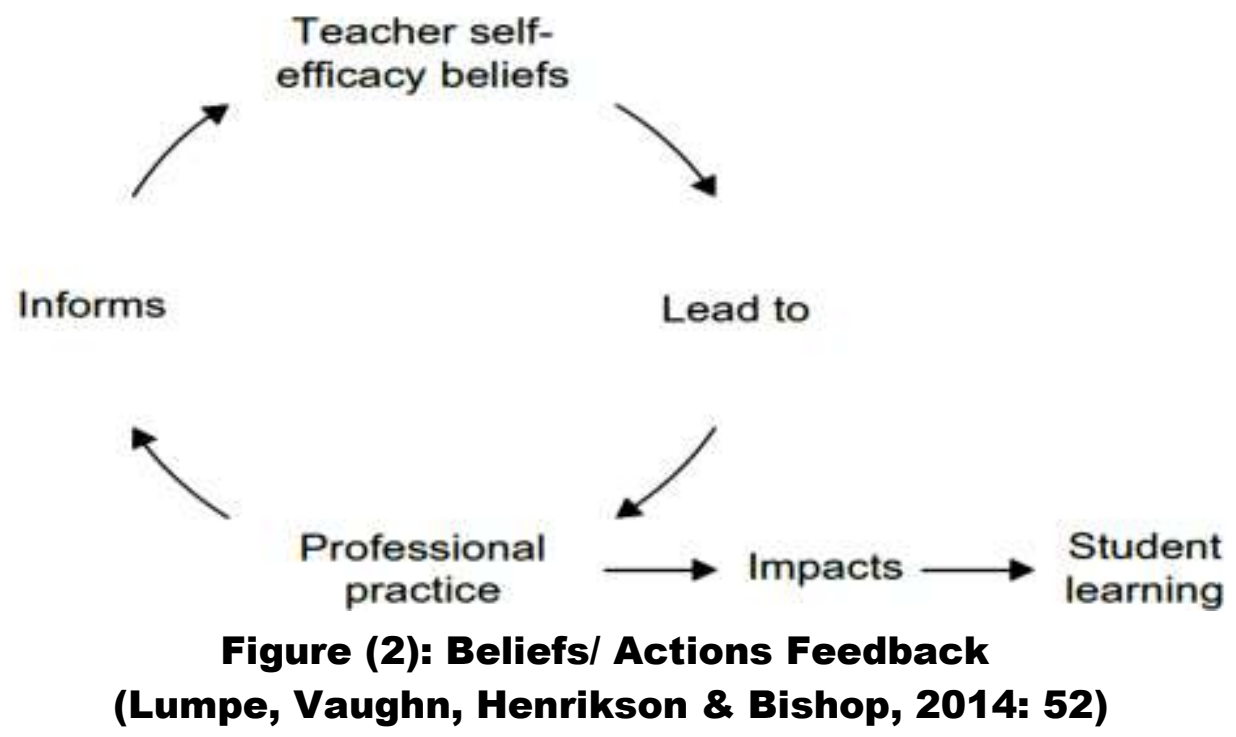

It can be said that student teacher's behaviors have an invisible complement (teacher beliefs). The latter constitute a determinant of the former, i.e., teachers' actions are influenced by their beliefs about the school, teaching and students. It has proven that teachers' belief in their own abilities positively affects the actions of teachers as well as motivation, styles of teaching, classroom management, students' learning and other teacher characteristics. 
Classroom is a social reality where student teachers interact with students, negotiate their beliefs and produce instructional practices. Therefore, it is a place where many dynamic contextual factors interact with each other and inform teachers' beliefs and practice. In this case, the initial codes are adopted using ecological approaches to divide the contexts into three systems: macro-system, exo-system and microsystem (Zheng, 2015:35).

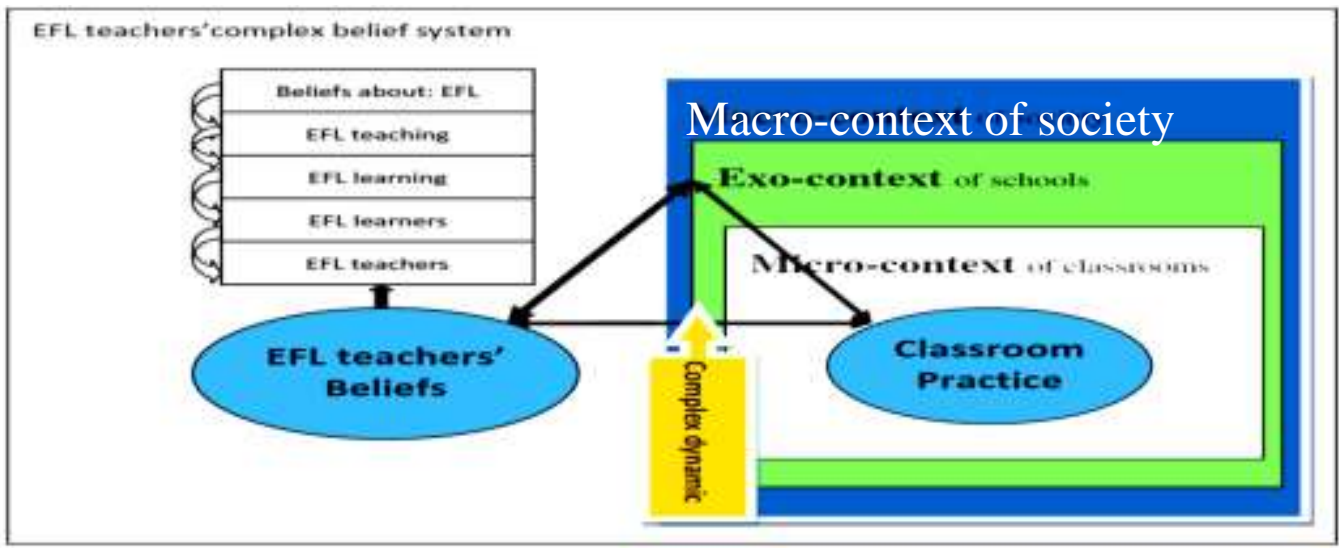

Figure (3): Elements in Teachers' Complex Belief System (Zheng, 2015:36)

Teachers' belief systems hold beliefs about EFL, EFL teaching and learning and EFL teachers and learners. They interact with each other, with instructional practices and with contexts, contributing to the complex dynamic nature of the systems.

\section{Sources of Teachers' Self-efficacy}

Bandura posited four main sources that influence efficacy: mastery experience, vicarious experience, verbal persuasion, and emotional arousal (Bandura, 1994: 71). These sources are shown in the figure:

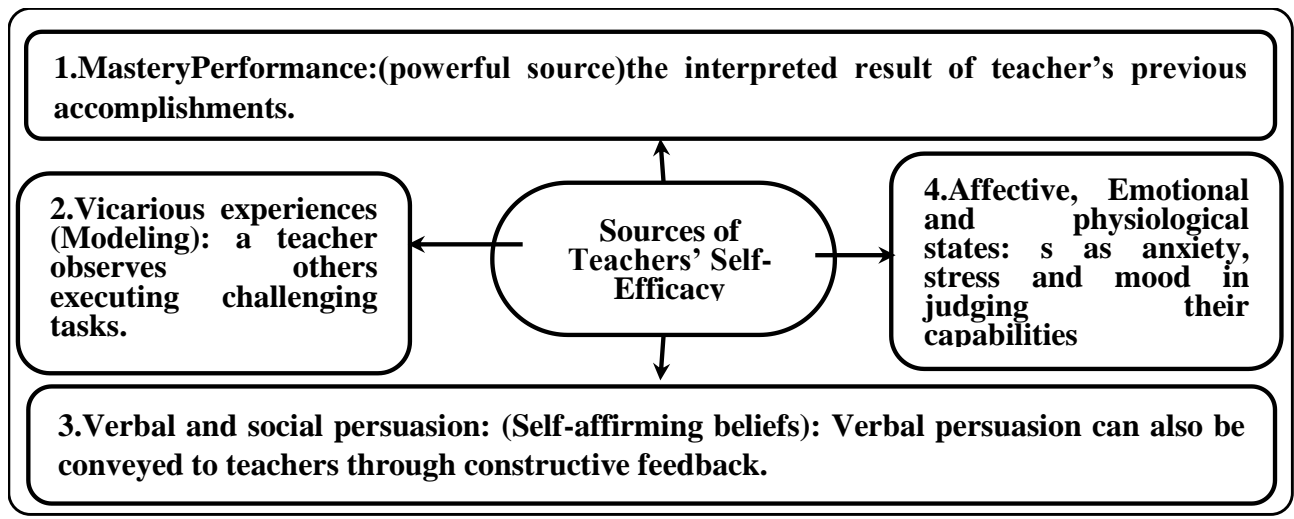

Figure (4): Sources of EFL Teachers' Self-Efficacy (Original Source) 
Therefore, deeper understanding of the mechanism by which teachers construct their beliefs and practice in specific contexts is critical to teachers' professional development and will further inform teacher education.

Due to the importance of EFL teaching self-efficacy among student teachers, many studies have tackled them. El-bassuony (2011) investigated the effectiveness of a treatment based on a collaborative action research and Facebook in developing EFL fourth year preservice teachers' perception of professionalism and efficacy. The results of the study revealed that the treatment was effective in developing pre-service teachers' perception of a professional teacher. Abd El-Gawaad (2016) investigated the effectiveness of Virtual Learning Environment (VLE) in developing teaching efficiency of $4^{\text {th }}$ year Basic Education studentteachers of English. Results revealed that the VLE was effective in developing 4th year Basic Education student-teachers' teaching efficiency. Ali (2016) investigated the effectiveness of a program based on the modified Sheltered Instruction Observation Protocol Model (SIOP) in developing teaching performance, self-assessment and sense of teacher efficacy of General Diploma teachers of English. Results revealed that the SIOP program was effective in developing General Diploma students' teaching performance, self-assessment and teacher efficacy sense. Hammam (2016) investigated how co-teaching can be used to develop instructional skills and the teaching self-efficacy among $33 \mathrm{EFL}$ fourth year student teachers. The findings revealed that co-teaching helped EFL student teachers develop their classroom performance skills and teaching self-efficacy. Also there is a positive relationship between EFL student teachers' instructional skills and their teaching self-efficacy. Ra'afat (2016) investigated the effect of using a blended e-learning program based on case study in teaching on developing personal teaching efficacy, language proficiency and creative thinking of third year English majors. Results showed that the treatment group achieved a higher degree of improvement than the non-treatment one on the post test of personal teaching efficacy skills, on the post test of language proficiency skills, and on the post test of creative thinking skills. 


\section{Problem Based Learning (PBL)}

Implementing PBL is an interrelated process that balances the student teachers' needs and the curriculum within a particular learning context through these steps:

1- A Problem Design: The Scenario: Tutors select problematic situations, knowing student teachers' needs (Filipenko \& Naslund, 2016: 63).

2- A Problem Presentation: Student teachers are given the "problem" presented in a number of ways identified by Papageorgiou, McCrorie, Georgiades and Perdikogianni (2015:20) as a case, photograph, film, an article from a professional journal or newspaper, and a real or simulated teacher. Pre-service teachers undertake the PBL in small groups (7-10). Each group or team has a leader. Choo (2012:168) outlined the stages of PBL in the following diagram:

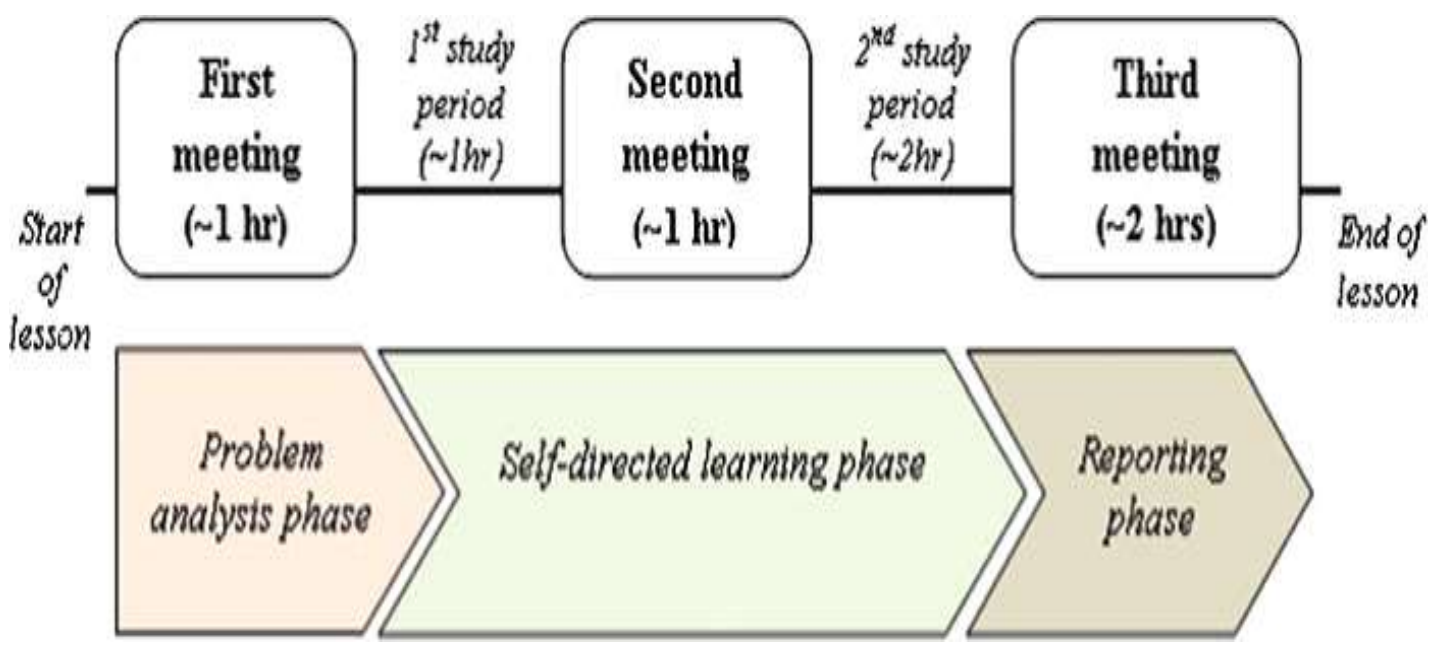

Figure(5):Schematic Diagram Illustrating an Overview of the PBL(Choo, 2012: 168)

3- First meeting (Problem analysis phase): Student teachers are given approximately 10 minutes to share their initial response to the problem in teams. Through group discussions, they fill up what it is called "a Problem Definition Template (PDT) " as a scaffolding tool, identifying what they knew, do not know and need to find out to address the problem (Grady, Yew, Goh \&Schmidt, 2012:7). 
Throughout the discussion, student teachers formulate learning issues or questions which they write up on the whiteboard or flipchart. The next step is self-study (Papageorgiou, McCrorie, Georgiades \& Perdikogianni, $2015,24: 25)$. By the end of the first meeting, they identify these gaps as learning issues to be studied further during the self-directed learning phase (first study period) (Grady, Yew, Goh \& Schmidt, 2012: 8).

- First study period (Self-Directed Learning Phase): After the first meeting, student teachers are given about an hour to carry out individual self-study and to work in their teams. They are provided with a learning scaffold in the form of a 'worksheet'. It provides relevant resources and breaks the problem down into smaller tasks or steps, thereby helping them to think through the problem systematically. By the end of the first study period, each team would be expected to answer at least in part, some of the questions raised in their PDT earlier (Grady; Yew, Goh \& Schmidt, 2012: 9).

4- Second meeting: The facilitator returns to the class during the second meeting to meet with the teams. Student teachers share their learning progress and strategy of understanding the problem. The facilitator helps them with their learning difficulties or facilitate building their conceptual understanding.

- Second study period (Self-directed Learning Phase): After their discussion with the facilitator, the teams continue their selfdirected study as a team discussion to consolidate their findings and formulate a response to the problem. What is important is that student teachers develop a learning artifact that they can use along with a verbal explanation to demonstrate their understanding (Choo, 2012: 169).

5- Third meeting (Reporting Phase): During the third meeting (reporting phase), each team presents their consolidated findings and response to the problem, elaborating, justifying and defending based on questions raised by peers and the facilitator. After all, the teams present their solutions to the problem; the facilitator will go through a brief presentation that provides a possible response to it (Grady; Yew, Goh \& Schmidt, 2012: 10). 
6- Reflection of learning process. At the end, student teachers reflect on the knowledge and skills acquired by completing a reflection journal.

\section{Method}

\section{Participants of the Research}

The participants of the research were (60) student teachers selected from the fourth year, English Section at Faculty of Education, Benha University. They were divided into two groups, one was control $(n=30)$ and the other was experimental $(n=30)$.

\section{Setting of the Research}

The study was applied to the fourth year student teachers, English Section in the Information Technology Unit (ITU) at Faculty of Education, Benha University.

\section{Instruments of the Research}

To achieve the purpose of the research, the following instruments were used: A scale of teaching self-efficacy beliefs (adopted from Hammam's final version, 2016,134:136) and A reflection form (prepared by the researcher)

\section{A Scale of Teaching Self-Efficacy}

\section{Purpose of A Scale of Teaching Self-Efficacy}

- The scale of teaching self-efficacy aimed to determine fourth year student teachers' beliefs concerning their ability to teach.

- Description of the Scale

- The scale was adapted from Hammam's final version $(2016,134: 136)$.

\section{Teaching Self-Efficacy Scale}

Please read the following items and then rate how certain you are that you can perform each of the following teaching skills. Rate your degree of confidence by recording a number from 1 to 5 using the scale given below:

\begin{tabular}{|l|l|l|l|l|l|l|}
\hline $\begin{array}{l}\text { 1: can't do } \\
\text { at all }\end{array}$ & $\begin{array}{l}\text { 2: can do to } \\
\text { some extent }\end{array}$ & $\begin{array}{l}\text { 3: can do } \\
\text { moderately }\end{array}$ & $\begin{array}{l}\text { 4: can do } \\
\text { well }\end{array}$ & $\begin{array}{l}\text { 5: can do highly } \\
\text { to a great extent }\end{array}$ \\
\hline
\end{tabular}


Please check One response that describes you. Be honest, since the information will be used to help you in school and also help you become more prepared for college and careers. There is no right or wrong answers!

\begin{tabular}{|c|c|c|c|c|c|c|}
\hline \multirow{3}{*}{ N. } & \multirow{3}{*}{$\begin{array}{c}\text { Teaching Self-Efficacy Items: } \\
\text { As an EFL Fourth Year Student } \\
\text { Teacher, I think l'm confident in my } \\
\text { ability to: }\end{array}$} & \multicolumn{5}{|c|}{ C } \\
\hline & & \multicolumn{5}{|c|}{ do } \\
\hline & & 1 & 2 & 3 & 4 & \\
\hline 1. & Warm-up my ss. before starting the lesson. & & & & & \\
\hline 2. & & $\square$ & & & & \\
\hline 3. & $\begin{array}{l}\text { the material (lesson) to the proper } \\
\text { my ss. }\end{array}$ & & & & & \\
\hline 4. & $\begin{array}{l}\text { Use various instructional media and/ } \\
\text { technology to support teaching and learning. }\end{array}$ & $\square$ & $\square$ & & & \\
\hline 5. & ves to be & & & & & \\
\hline 6. & orrect. & & & & & \\
\hline 7. & Attrac & & & & & \\
\hline 8. & o follow classroom rules and & & & & & \\
\hline 9. & $\begin{array}{l}\text { mmar and structures effectively } \\
\text { tingly. }\end{array}$ & & & & & \\
\hline & & & & & & \\
\hline & & & & & & \\
\hline 12. & the & & & & & \\
\hline 13. & ticipation. & & & & & \\
\hline 14. & & L & & & & \\
\hline 15 & oral- & & & & & \\
\hline 16. & & & & & & \\
\hline 17. & uptive behavior in an & & & & & \\
\hline & $\begin{array}{l}\text { ar voc. using various } \\
\text { es. }\end{array}$ & & & & & \\
\hline 19. & & & & & & \\
\hline 20. & kes and/or errors in an & ـ & & & & \\
\hline 21. & $\begin{array}{l}\text { ks and activities that suit low and } \\
\text { ss. }\end{array}$ & $\square$ & & & & \\
\hline 22. & & L_ & & & & \\
\hline 23. & & $\square$ & & & & \\
\hline 24. & & & 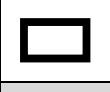 & $\square$ & & \\
\hline & $\begin{array}{l}\text { se my ss' first language( } \\
\text { inctional manner. }\end{array}$ & & 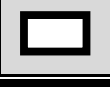 & & & \\
\hline
\end{tabular}




\section{Scoring the Scale:}

The total score of the scale was calculated by adding the numbers associated with responses to each item. As the scale ranged from 1 to 5 as shown in the table above. Thus, the highest score was 125 and the lowest was 25 .

\section{The Reflection Form}

\section{Purpose of the Reflection Form}

The Reflection Form was a self-report of student teachers' teaching self-efficacy before and after the PBL.

\section{Description of the Reflection Form:}

The Reflection Form consisted of eight questions that determined student teachers' self-efficacy before and after the PBL. An example of questions in the Reflection Form is "Describe your teaching experience before \& after the PBL program (Your teaching knowledge, skills, view about yourself as a teacher, and self-confidence)

\section{The Problem Based Learning (PBL) Treatment}

\section{Y Purpose of the Problem Based Learning}

Using PBL aimed at promoting EFL teaching self-efficacy beliefs among fourth year student teachers, Faculty of Education, Benha University.

\section{Duration of the $P B L$}

The PBL treatment lasted for 8 weeks at a rate of three sessions a week, and every session lasted for 60 minutes.

\section{Description of the PBL Treatment}

The PBL treatment consisted of twenty-five sessions taught by the researcher according to the permission letter for the experiment. First, a pre-post teaching self-efficacy scale was administered to the two groups; the control group and the experimental group. In order to investigate the 
effectiveness of the PBL in improving EFL teaching self-efficacy among fourth year student teachers at Faculty of Education Benha University, a framework of the PBL treatment was prepared and outlined. The PBL handled the specified EFL teaching self-efficacy beliefs related to teaching tasks: engaging students, classroom management and instructional strategies. The instructor's or tutor's manual was designed according to the procedures of PBL.

\section{Post - Scaling}

On the $13^{\text {th }}$ of Dec. 2018 , the post-teaching self-efficacy scale was administered to both the control and the experimental groups. Finally, data was collected.

\section{Results of the Research}

\section{Validating the Hypothesis}

The hypothesis stated that "there is a statistically significant difference between the mean scores of the experimental group and the control one on EFL teaching self-efficacy in the post-assessment at the level of $\alpha 0.05$, in favor of the experimental group".

Table [1] presents t-value and the level of significance of both experimental and the control one of EFL teaching self-efficacy in the post assessment.

Table [1]: Findings of "T" test between the experimental group and the control one of EFL teaching self-efficacy in the post-assessment

\begin{tabular}{|c|c|c|c|c|c|c|c|}
\hline Item & Group & N. & Mean & S.D & T-Value & D.F & Sig. \\
\hline \hline $\begin{array}{c}\text { EFL Teaching } \\
\text { Self-Efficacy }\end{array}$ & Exp. & 30 & 104.3 & 9.20 & \multirow{2}{*}{13.12} & \multirow{2}{*}{58} & \multirow{2}{*}{0.05} \\
\cline { 2 - 5 } & Cont. & 30 & 78.0 & 5.92 & & \\
\hline
\end{tabular}

Table [1] shows that there is a statistically significant difference between the mean scores of the experimental group and the control one of EFL teaching self-efficacy in the post-assessment, in favor of the experimental group, where t-value is (13.12) which is significant at the (0.05) level of significance. Thus, the hypothesis is accepted. This finding is consistent with the studies of El-bassuony (2011) and Hammam (2016). This difference can be attributed to using PBL. 
- The size of the effectiveness of the PBL $\left(\eta^{2}\right)$ in improving teaching self-efficacy for the experimental group student teachers in the pre/post-assessment.

Table [2]: Findings of the PBL (n2) in developing EFL teaching self efficacy for the experimental group student teachers in the pre/post-assessment

\begin{tabular}{||c|c|c|c|c|c|c|c|}
\hline Assessment & Group & N. & Mean & S.D & T-Value & D.F & n2 \\
\hline \hline $\begin{array}{c}\text { Pre-post self- } \\
\text { efficacy scale }\end{array}$ & Exp. & 30 & 13.26 & 6.43 & 11.29 & 29 & $\mathbf{8 1 . 4 8}$ \\
\hline
\end{tabular}

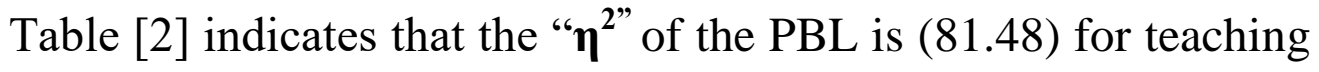
self-efficacy in the pre/post- assessment. This signifies that PBL is effective in developing EFL teaching self-efficacy among fourth year EFL student teachers.

\section{Discussion of the Results}

The aim of the present research was to develop EFL teaching selfefficacy among the fourth year student teachers using PBL. The PBL helped them reflect on their experiences in real contexts /classrooms. They identified their teaching problems using strategic thinking. They identified what they knew, what they wanted to know (learning needs or issues), how to know (sources of knowledge), how to solve their problem (strategy of solution). They become self-directed learners, searching information from different resources, locating potential useful information, sharing it and collecting it to complete the whole picture of the situation. They negotiated with each other's, organized their roles, shared their knowledge, selected the appropriate solving strategy, solved the problem, modelled the solution and reflected on the whole experience. They debriefed the problem, what they learned, valued, benefited. They found themselves confident in dealing with such complex situations in their real classrooms. Thus, using the PBL developed the experimental group student teachers' teaching selfefficacy. This result was consistent with the results of many previous studies: (Abd El-Gawad, 2016, Ali, 2016 \&Al-Shukri, 2016). 
The results of the present research also revealed that there is a close relationship between EFL teaching self-efficacy and the PBL. Through inquiry, pre service teachers learn to become self- efficient teachers. By exposing pre-service teachers to this type of thinking and reflection, their professional dispositions can be awakened so that they embrace and value learning and discover answers for themselves. In PBL, pre-service teachers participate as members of a community of learners. This environment of trust has been recognized as important in the development of a culture of inquiry (Naslund\& Prodan, 2016: 28).

\section{Conclusions}

The main conclusion was that PBL was effective in promoting EFL self-efficacy among fourth year student teachers at Faculty of Education, Benha University

\section{Recommendations}

In the light of previous results, the following recommendations could be presented:

- PBL should be used to improve EFL teaching self-efficacy among student teachers at the Faculties of Education in Egypt.

- Student teachers should demonstrate their ability for self- directed learning, self-regulating, decision making, problem solving, ...etc which became necessary requirements in Teacher Education Programs (TEPs).

- EFL TEPs should emphasize the supportive environment for student teachers through considering their professional identity as teachers from one side and as learners from another side.

\section{Suggestions for Further Research}

Based on the findings of the present research, the followings are implications for further research:

- Exploring the impact of teachers' teaching self-efficacy on developing students' EFL language skills.

- Investigating the Problem Based Learning in improving classroom management skills and teaching self-efficacy among EFL student teachers.

- Investigating the effectiveness of a teaching self-efficacy based program in developing EFL teaching skills among EFL student teachers. 


\section{References}

Abd El-Gawaad,R. (2016). The effectiveness of virtual learning environment in developing teaching efficiency of Basic Education Student Teachers of English. Ph.D. Dissertation, Faculty of Education, Assiut University

Ahmed,S.(2014). The effect of logging on EFL student teachers' teaching self-efficacy. Research in Curriculum, Instruction and Educational Technology, Vol.1, N. (1)

Ali,A.(2016). The Effectiveness of a Program Based on the Modified Sheltered Instruction Observation Protocol Model (SIOP) in Developing Teaching performance, Self-Assessment and Sense of Teacher Efficacy of Teachers of English. Ph.D. Dissertation, Faculty of Education, Assiut University

Bandura, A. (1994). Self-efficacy. In V. S. Ramachaudran (Ed.), Encyclopedia of Human Behavior (Vol. 4, pp. 71-81). New York: Academic Press. (Reprinted in H. Friedman [Ed.], Encyclopedia of mental health. San Diego: Academic Press.

Bandura, A. (1997). Self-efficacy: The exercise of control. New York, NY: W. H. Freeman

Blonder, R.; Benny, N. \& Jones, M.(2014). Teaching self-efficacy teachers. In R., Evans ; J., Luft ; C., Czerniak,; \& C., Pea, (2014). The Role of Science Teachers' Beliefs in International Classrooms: From Teacher Actions to Student Learning. The Netherlands: Sense Publishers

Borg, S. (2011). Comteporary themes in language teacher education. In Y. Wu \& Z. Lian (Eds.), FLTED in China 2009 Paper presented at the 3rd national symposium on foreign language teacher education and development (pp. 3-15). Beijing: Foreign Language Teaching and Research Press. 
Brears, L.; MacIntyre, B.; O'Sullivan, G. (2011). Preparing teachers for the 21st century using PBL as an integrating strategy in Science and Technology Education. Massey College of Education, New Zealand. Eric EJ 916495. Design and Technology Education, Vol.16, N.1, pp36-46.

Choo, S. (2012). Scaffolding in Problem-based Learning. In Grady, G.; Yew, E. \& Schmidt, G. (2012). One-Day, One-Problem: An Approach to Problem-based Learning. Singapore. Springer Science+Business Media.

El-bassuony, J. (2011). Using collaborative action research and Facebook to develop EFL pre-service teachers' professionalism in the light of STEPS standards. Studies in Curriculum and Instruction, 176,1-48

El-Sweedy, N. (2012). The effect of a suggested program on developing beliefs and teaching skills related to writing among EFL prospective teachers. Ph.D. Dissertation, Faculty of Education, Benha University

Faculties of Education Enhancement Project (FOEP) (2005). A Practical Education Guide. Ministry of Higher Education, Cairo.

Filipenko, M. \& Naslund, J. (2016). Problem-Based Learning in Teacher Education. New York: Springer International Publishing Switzerland

Gavora, P. (2011). Measuring the self-efficacy of in-service teachers in Slovakia. Comenius University, Bratislava. Orbis Scholae, vol.5, No.2, pp.79-94.

Grady, G.; Yew, E.; Goh, K. \& Schmidt, G. (2012). One-Day, OneProblem: An Approach to Problem-based Learning. Singapore. Springer Science+Business Media. 
Hammam, E. (2016). Developing EFL student teachers' classroom performance skills and teaching self-Efficacy through CoTeaching. MA. Thesis, Faculty of Education, Menoufia Univesity

Hmelo-Silver, C.\& Barrows, H. (2008). Facilitating collaborative knowledge building. Cognition and Instruction, Vol. 26, N. 1, pp. 48-94

Lumpe,A. ; Vaughn, A. ; Henrikson, R. \& Bishop, D.(2014). Teacher Professional Development and Self-efficacy Beliefs. In Evans,R. ; Luft,J. ; Czerniak,C. ; Pea, C. (2014). The Role of Science Teachers' Beliefs in International Classrooms: From Teacher Actions to Student Learning. The Netherlands: Sense Publishers

Miller, M. (2008). Problem-Based Conversation: Using pre-service teachers' problems as a mechanism for their professional development. Teacher Education Quarterly. On Eric EJ838702

Mueller, A., \& Skamp, K. (2003) Teacher candidates talk: Listen to the unsteady beat of learning to teach. Journal of Teacher Education, Vol. 54, N. 5, pp. 428-440

Naslund,J. and Prodan, L. (2016). Dispositions for Inquiry. In Filipenko, M. \& Naslund, J. (2016). Problem-Based Learning in Teacher Education. New York: Springer International Publishing Switzerland

Papageorgiou, A. ; McCrorie,P.; Georgiades,S.;\& Perdikogianni, M. (2015). Psychology for Psychologists: A Problem Based Approach to Undergraduate Psychology Teaching.UK: Palgrave Macmillan

Peters, J. (2006). Engaging student teachers through the development and presentation of problem-based scenarios. Paper presented at the AARE Conference, Adelaide 
Sale, D. (2015). Creative Teaching: An Evidence-Based Approach. Singapore: Springer Science+Business Media

Toba, N. (2006). Standards for Teachers of English at Pre-Service (STEPS). Education Reform Program. Faculties of Education Development Unit. USAID(united states agency international development).

Toulouse, K., Spaziani, R. and Rangachari, P. (2012). A Backward Glance, the Forward Gaze: Evaluation in Problem-Based Courses. In Bridges, S.; McGrath, C. \& Whitehill, T. (2012). Problem-Based Learning in Clinical Education: The Next Generation. London: Springer Dordrecht Heidelberg.

Walker, A. \&Leary, H. (2009). A problem-based learning meta-analysis: Differences across problems types, implementation types, disciplines, and assessment levels. Interdisciplinary Journal of Problem-Based Learning, Vol.3, N. 1, pp. 12-43.

Zheng, H. (2015) Teacher Beliefs as a Complex System: English Language Teachers in China, English Language Education. Switzerland: Springer International Publishing 